\title{
Trichomegaly associated with panitumumab: Case report
}

\section{Panitumumab İlişkili Trikomegali: Olgu Sunumu}

\author{
Yakup Ergün, Mutlu Doğan, Öznur Bal, Ozan Yazıcı, Gökhan Uçar, Nurullah Zengin \\ Ankara Numune Eğitim ve Araştırma Hastanesi, Tıbbi Onkoloji Kliniğgi
}

Dergiye Ulaşma Tarihi:21.11.2017 Dergiye Kabul Tarihi:05.12.2017 Doi: 10.5505/aot.2018.83097

\section{ÖZET}

Epidermal büyüme faktörü reseptörü (EGFR) inhibitörleri, malign epitelyal tümörlerin tedavisinde yaygın olarak kullanılmaktadır. Bu ajanların kullanımında en sık gözlenen yan etki cilt toksitesi iken trikomegali nadir görülen bir yan etkidir. Burada, metastatik kolon karsinomu nedeniyle panitumumab kullanan ve trikomegali gelişen 48 yaşındaki kadın olgu literatür eşliğinde sunulmuştur.

Anahtar Kelimeler: panitumumab, trikomegali, kolorektal karsinom

ABSTRACT
Epidermal growth factor receptor (EGFR) inhibitors are widely used in the treatment of malignant epithelial tumors. Trichomegaly is a rare side effect while skin toxicity is the most common side effect of using these agents. In here, a 48-year-old female with trichomegaly using panitumumab due to metastatic colon carcinoma was presented in the literature.

Keywords: panitumumab, trichomegaly, colorectal carcinoma

\section{GİRIŞ}

Epidermal büyüme faktör reseptörü (EGFR), ErbB ailesine ait bir transmembranöz glikoproteindir. EGFR sinyal yolağı hücre farklılaşması ve proliferasyonun yanı sıra apopitozisin düzenlenmesinde önemlidir (1). Kıl folikülünün dış kısmında bulunan kıl k1lıfindaki keratinositlerde de bulunan EGFR anagen fazının başlamasının yanı sıra bitmesinde ve k1l büyümesinde önemli bir rol oynar. EGFR sinyalinin baskılanmas1 anagenden telogene geçişi engelller ve disorganize kıl folikülü oluşumu ile sonuçlanır (2).

Panitumumab saf humanize $\operatorname{IgG} 2$ monoklonal antikor olup RAS mutasyonu olmayan metastatik kolorektal karsinomda etkin bir ajandır (3) Anti EGFR ajanların en sık görülen yan etkisi olan cilt toksitesi EGFR monoklonal antikor tedavisi için prediktif bir faktördür (4) Panitumumab alan hastalarda akneiform döküntü, kserozis, paronişi gibi dermatolojik yan etkilerle siklıkla görülürken Panitumumab ilişkili kirpik uzaması (trikomegali) literatürde vaka bildirimleri şeklinde bildirilmiştir (5). Burada, panitumumab ilişkili trikomegali ve hipertrikozis gelişen 48 yaşındaki kadın olgu literatür eşliğinde sunulmuştur.

\section{OLGU SUNUMU}

48 yaşında kadın hasta karın ağrısı şikayetiyle dış merkezde Acil Servis'e başvurmuş. Tetkikler sirasında adneksiyal kitle saptanarak operasyona alınan hastanın peroperatif değerlendirmesinde sigmoid kolonda da kitle izlenmesi üzerine jinekolojik olarak planlanan cerrahiye sol hemikolektomi de eklenmiş. Patoloji sonucu; Kolon Orta Derece Differansiye Adenokarsinom; omentum, mesane, her iki over, apendikste metastaz ile uyumlu gelmesi üzerine hasta merkezimize yönlendirilmiş. Başvuru anında fizik muayenede anlamlı patoloji izlenmeyen hastanın torako-abdominal bilgisayarlı tomografisinde; karaciğer ve dalakta multipl metastaz izlendi. K-RAS, N-RAS ve BRAF mutasyonu izlenmeyen hastaya evre 4 kolon kanseri tanisiyla hastaya FOLFOX (oksaliplatin, 5FU, lökovorin) ve panitumumab 
başland1. Altı hafta sonra özellikle çene bölgesinde belirgin olmak üzere vücutta kıllanma artış1, sonraki uygulamaları takiben de kirpiklerde belirgin uzama görüldü. Fizik muayenede; yüz bölgesinde akneiform döküntü, erkek tipinde kıllanmada artış, kaşlarda kalınlaşma ve kirpikler ise bilateral kalın, düzensiz, anormal uzun izlendi (Resim 1, 2). Laboratuvar tetkiklerinde herhangi bir anormallik izlenmedi. Trikomegaliye yönelik tedavi periyodik kısaltma dışında ek bir öneride bulunulmadi. FOLFOX-panitumumab tedavisi ile parsiyel yanıt elde edilen hastanın tedavisine ve takibine devam edilmektedir.

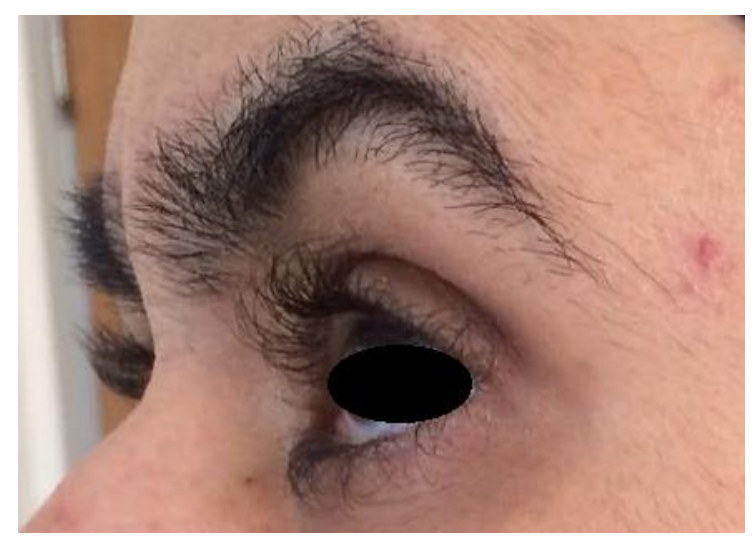

Figür 1: Kaş ve kirpiklerde uzama

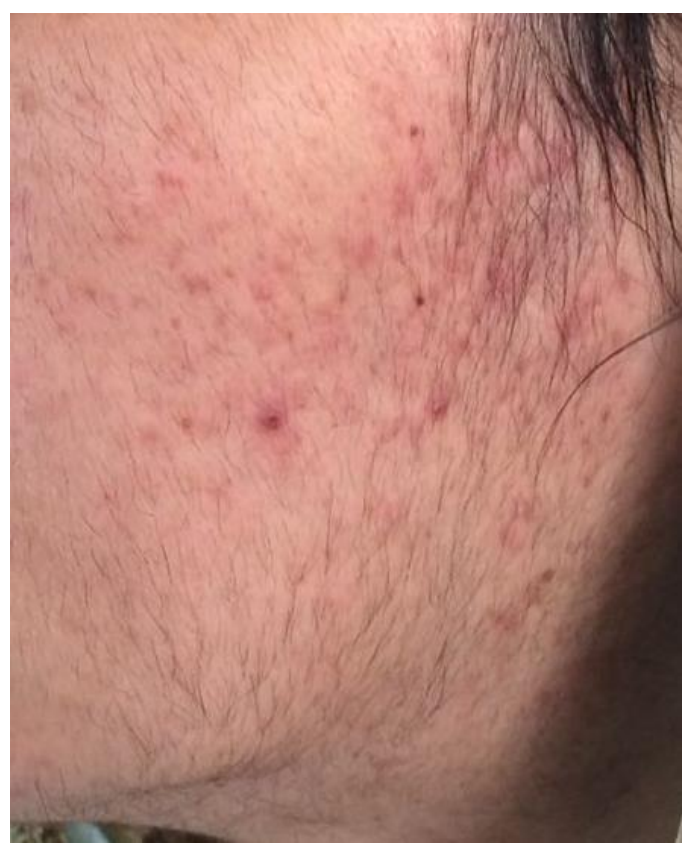

Figür 2: Yanak ve çenede erkek tipi kıllanma artış1

\section{TARTIŞMA}

Trikomegali, kirpiklerin anormal büyümesi ve uzaması olarak tanımlanmaktadır. EGFR inhibitörleri ile ilişkili trikomegali, karakteristik olarak uzun, kıvırcık kirpiklerle karakterizedir. Kaşlar kalınlaşır, bazen lateral incelme eşlik eder, nadiren kaşlar lateral periorbital alana yayılır veya orta hatta birleşebilir (2). Trikomegaliye sebep olan ilaçlar Tablo 1'de gösterilmiştir (6). Literatürde anti-EGFR ajanlarla (setuksimab, erlotinib gibi) ilişkili trikomegali olguları vaka serileri şeklinde sunulmaina rağmen panitumumab ile ilişkili trikomegali oldukça nadirdir (7-9).

Anti EGFR ile ilişkili trikomegali genellikle kozmetik problem dişında sorun yaratmayan, hafif seyirli bir yan etkidir. Ancak, bazı vakalarda kornea ülserine yol açacak kadar ileri düzeyde olabilir (10) Bu durum hem ciddi göz komplikasyonlarına hem de komplikasyon nedeniyle tedaviye ara verilmesi veya kesilmesine bağlı olarak kanser tedavisinin aksamasına neden olabilir. Kozmetik olarak periyodik kısaltma önerilebilir. Biz de hastamıza periyodik kısaltma önerdik. Daha komplike vakalar dermatoloji ve göz hastalıkları uzmanı ile birlikte multidisipliner olarak değerlendirilmelidir (10). Daha önce de vurgulandığı üzere cilt toksitesi anti-EGFR tedaviye yanıt açısından prediktif olarak kabul edilmektedir ancak trikomegalinin prediktif değeri için yeterli veri bulunmamaktadır. Köksal UI ve arkadaşları setuksimab uygulanan dört vakanın sunulduğu makalelerinde trikomegalinin prediktif olmadığını belirtmişlerdir (7). Ancak, trikomegalinin prediktif değeri için daha çok sayıda hasta içeren prospektif klinik çalışmalara ihtiyaç vardır. Literatürde trikomegalinin geri dönüşlü olduğu ve genellikle tedavi kesildikten sonra 12 ay içerisinde gerilediği bildirilmiştir $(8,9)$.

Sonuç olarak; trikomegali anti-EGFR tedavi sırasında nadir görülen bir yan etkidir. Genellikle hafif seyirli olup tedavi gerektirmemektedir. Komplike vakalar göz hastalıkları ve dermatoloji uzmanlarıla birlikte değerlendirilmelidir. 
Tablo 1. Trikomegaliye sebep olan ilaçlar

\begin{tabular}{|c|c|}
\hline $\begin{array}{l}\text { Trikomegaliye } \\
\text { sik neden olan } \\
\text { ajanlar }\end{array}$ & $\begin{array}{l}\text { EGFR-monoklonal antikorlar } \\
-\quad \text { setuksimab } \\
\text { Tiozin kinaz inhibitörleri } \\
-\quad \text { erlotinib } \\
\text { Prostaglandin analoglar1 } \\
-\quad \text { bimatoprost } \\
-\quad \text { latanoprost }\end{array}$ \\
\hline $\begin{array}{l}\text { Trikomegaliye } \\
\text { nadir neden } \\
\text { olan ajanlar }\end{array}$ & 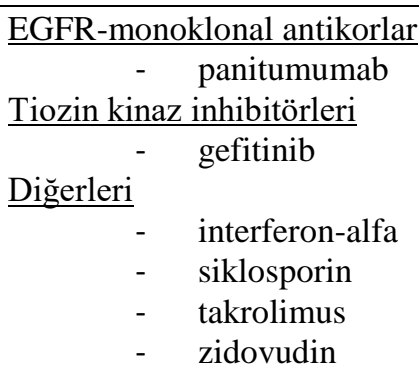 \\
\hline
\end{tabular}

Çıkar çatışması: Yazarlar çıkar çatışması olmadığını beyan etmektedir.

\section{REFERANSLAR}

1. Seshacharyulu $P$ et al. Targeting the EGFR signaling pathway in cancer therapy. Expert Opin Ther Targets. 2012 Jan; 16(1): 15-31.

2. Kılıç A. Inhibitors of Epidermal Growth Factor Receptor and Dermatological Side Effects. Turk J Dermatol 2012; 6: 168-74.
3. Wells A. Panitumumab, a Monoclonal AntiEpidermal Growth Factor Receptor Antibody in Colorectal Cancer: Another One or the One?. Clin Cancer Res 2007;13(16):4664-4666.

4. Petrelli $\mathrm{F}$ et al. The predictive role of skin rash with cetuximab and panitumumab in colorectal cancer patients: a systematic review and metaanalysis of published trials. Target Oncol. 2013 Sep;8(3):173-181.

5. Hofheinz RD et al. Management of adverse events during treatment of gastrointestinal cancers with epidermal growth factor inhibitors. Crit Rev Oncol Hematol. 2017 Jun; 114:102113.

6. Paul LJ et al. Eyelash trichomegaly: Review of congenital, acquired, and drug-associated etiologies for elongation of the eyelashes. Int $\mathbf{J}$ Dermatol 2012; 51:631-46.

7. Koksal UI et al. Trichomegaly Induced by Cetuximab: Case Series and Review the Literature. Am J Ther. 2016 SepOct;23(5):e1226-9.

8. Wang SB et al. Eyelash trichomegaly following treatment with erlotinib in a non-small cell lung cancer patient: A case report and literature review. Oncol Lett. 2015 Aug; 10(2): 954-956.

9. L.G.T. Morris et al. Eyelash trichomegaly secondary to panitumumab therapy. Curr Oncol. 2011 Jun; 18(3): 145-146.

10. Lane $\mathrm{K}$ et al.Erlotinib-associated trichomegaly. Ophthal Plast Reconstr Surg. 2007 JanFeb;23(1):65-6.

11. Zhang $G$ et al. Acquired trichomegaly and symptomatic external ocular changes in patients receiving epidermal growth factor receptor inhibitors. Cornea. 2007;26:858-60. 